\title{
MEMÓRIA E SILENCIAMENTO: a cobertura do jornal O Globo sobre o Cemitério dos Pretos Novos
}

\author{
Mônica C P Sousa ${ }^{1}$ \\ Larissa Siqueira $^{2}$
}

Resumo: Partindo do entendimento de que o jornalismo reorganiza significados, este trabalho se propõe a problematizar o alijamento das vozes negras na cobertura jornalística sobre o Cemitério dos Pretos Novos em O Globo. De que maneira arranjos estratégicos tomam forma no jornalismo? Essa questão nos leva a uma chave de interpretação do papel do jornalismo em neutralizar e silenciar o potencial questionador das falas e da memória negra na história da cidade do Rio de Janeiro e do Brasil. O que nos interessa, então, é problematizar como o jornalismo registra e controla a produção do sentido. Sendo assim, do ponto de vista metodológico, a pesquisa não se propõe a considerações quantitativas, mas buscará uma delimitação que permita a análise dos discursos jornalísticos a partir dos pressupostos teóricos de Foucault, Orlandi, Benjamin e Gagnebin.

Palavras-chave: Jornalismo, silenciamento, memória, negros, O Globo.

Abstract: This paper aims to analyze how journalism reorganizes meanings. The objective is to understand the silencing of black voices in the journalistic coverage of the Cemetery of the New Blacks in O Globo. In what ways do strategic arrangements take shape, not journalism? This question leads us to interpret the role of journalism in neutralizing and silencing the questioning potential of false and black memory in the history of the city of Rio de Janeiro and Brazil. What interests us, then, is to problematize how journalism registers and controls the production of meaning. Thus, from the methodological point of view, the research does not apply to quantitative quantities, but rather a delimitation that allows an analysis of the journalistic discourses from the theoretical assumptions of Foucault, Orlandi, Benjamin and Gagnebin.

Keywords: Journalism, silencing, memory, black people, O Globo.

\section{Introdução}

Lá fora havia o matraquear da morte, lamentos de vidas que se apagavam. Para nós, porém, aquele ruído era já parte da paisagem. Ficava, contudo, um amargo escorrendo naquelas paredes.

O texto de abertura do livro Vozes Anoitecidas, publicado pela primeira vez em 1986 do autor moçambicano Mia Couto, traz uma forma de contemplar as desigualdades do mundo que dão a tônica da importância da memória para, senão a superação, os encontros de formas de resistência aos lugares subterrâneos e subalternos na formação histórica de uma nação: “O que mais dói na miséria é a ignorância que ela tem de si mesma. Confrontados com a ausência

${ }^{1}$ Pós-doutoranda pelo PPGCom UERJ, doutora pelo PPGCom da UFF. Pesquisadora no grupo Geografias da Comunicação. Docente da Universidade Veiga de Almeida.

${ }^{2}$ Universidade Veiga de Almeida e jornalista na Rádio Cabo Frio FM $(89,3)$

${ }^{3}$ COUTO, Mia. Terra Sonâmbula, Cia das Letras, 1992, p.110. 
de tudo, os homens abstêm-se do sonho, desarmando-se do desejo de serem outros. Existe no nada essa ilusão de plenitude que faz parar a vida e anoitecer as vozes" (Couto, 2013, p.17). É por esse caminho que propomos um olhar para a problematização da memória da escravidão negra no país, a partir da lógica jornalística. Nossa proposta é buscar compreender as discrepâncias entre a teoria e a prática jornalísticas - ou mais precisamente, na maneira como a articulação entre ambas cria um confortável respaldo às empresas jornalísticas, no qual o engessamento dos rituais jornalísticos se tornam forças estratégicas e contrariam a essência "social" que esses rituais de objetividade, imparcialidade e verdade dizem defender.

Para responder às questões acerca de como e porque o silenciamento da memória negra se manifesta, foi realizada uma análise documental da cobertura do jornal $O$ Globo sobre fatos da história do Cemitério dos Pretos Novos, localizado na Zona Portuária do Rio de Janeiro. Como recorte temporal foram selecionados os anos de 1996, quando a necrópole foi descoberta, 2005, quando o sítio arqueológico se tornou um instituto de pesquisa, 2010, quando as especulações sobre as obras na Zona Portuária do Rio de Janeiro começaram e 2017, quando uma crise financeira alcançou o Museu e o Instituto.

A história da região e dos negros recém-chegados ao Rio de Janeiro ressurgiu do subsolo em janeiro de 1996. Moradores da Rua Pedro Ernesto, no bairro da Gamboa, Zona Portuária do Rio de Janeiro, iniciaram uma reforma no sobrado em que moravam. A casa construída no século XVIII, agora ocupada pelo casal Guimarães, foi escavada e revelou centenas de fragmentos de ossadas, cacos de cerâmica e vidro abaixo do piso. Após análise arqueológica foi constatado que ali, duzentos anos antes, havia funcionado o cemitério dos Pretos Novos, onde eram depositados os corpos dos negros recém-chegados da África que morriam nas casas de engorda ${ }^{4}$ antes de serem vendidos. A existência da necrópole vinha sendo ignorada desde a proibição do tráfico negreiro pelo Atlântico, em 1831. (PEREIRA, 2007.)

Naquela época, apenas os brancos tinham o privilégio do sepultamento próximo a Deus e ao paraíso, em igrejas. O destino dos negros era, inevitavelmente, o Cemitério dos Pretos Novos. De acordo com registros encontrados no Arquivo Geral da cidade do Rio de Janeiro, apenas do ano de 1824 a 1830, foram sepultados ali 6.122 negros recém-aportados. Todos em um espaço físico aproximado de 50 braças em quadra, medida utilizada na época, que hoje equivale a 110 metros - essas foram medidas encontradas por historiadores em

\footnotetext{
${ }^{4}$ Locais onde os negros escravizados passavam um período de quarentena para serem alimentados, ganharem peso e serem comercializados.
} 
registros antigos da cidade do Rio de Janeiro, mas o cemitério pode ser maior do que se tem conhecimento. Os corpos eram amontoados uns sobre os outros e ficavam dias sem que houvesse nenhuma cobertura de terra ou cal. Até a descoberta do casal Guimarães, não se sabia qual era a localização do cemitério, que foi durante muito tempo tratado como "mais uma lenda" dos tempos de escravidão.

Em À flor da terra: cemitério dos Pretos Novos no Rio de Janeiro (2007), Júlio César Medeiros aponta como o viajante alemão G. W. Freireyss descreveu o Cemitério dos Pretos Novos ainda no ano de 1814: "no meio deste espaço [de 50 braças] havia um monte de terra da qual, aqui e acolá, saíam restos de cadáveres descobertos pela chuva que tinha carregado a terra e ainda havia muitos cadáveres no chão que não tinham sido ainda enterrados. (PEREIRA apud FREIREYSS, 2007, p.8) Historiadores do Instituto de Pesquisa e Memória Pretos Novos encontraram nos registros 52 nomes de pretos recém-chegados. Eram denominados em óbito, na maioria das vezes, apenas com o primeiro nome. Geralda, Rita, Maria, João Congo, Adão "Escravo de Hum Padre" ou até "Filha de uma escrava Thereza" são alguns dos codinomes presentes nos registros. Todos os dados são disponibilizados pelo Instituto Pretos Novos.

\section{Condição humana mais miserável não existe, não dá para imaginar ${ }^{5}$}

A memória, materializada em ossos de escravos africanos recém-chegados no Brasil, ressurgiu na Gamboa no primeiro mês do ano de 1996, mas só apareceu no o O Globo no dia 25 de fevereiro. Por meio de uma nota no canto superior da página 3 do segundo caderno é dito que "uma importante descoberta acaba de ser feita pelo Departamento de Patrimônio Cultural da Prefeitura". (O GLOBO, 1996, p.3) Como única fonte para a construção da nota e aspas s faz uso da fala da secretária municipal de Cultura, Helena Severo: "Esse é um trabalho que pode contribuir para a história da cidade, desde suas origens" (O GLOBO, 1996, p.3) Vale lembrar que o fossário de negros, antes esquecido pelo Estado e tratado como lenda urbana, ressurgiu aos olhos do casal Guimarães por acaso, não por meio de algum esforço de instituições ligadas ao governo.

Uma matéria com duas colunas de texto tentou explicar melhor a descoberta no dia 27 de fevereiro, dois dias após a nota. Apesar de trazer mais fontes, a matéria apresenta somente

\footnotetext{
${ }^{5}$ Levi. Primo. É isto o homem? 1988, p 32.
} 
o fato com pequeno conteúdo histórico. Foram ouvidos a proprietária da casa construída sobre a necrópole, Ana Maria de La Merced, novamente a Secretária de Cultura da época, uma antropóloga da Prefeitura do Rio de Janeiro, o Diretor do Departamento de Patrimônio Cultural, também da Prefeitura, e um historiador da Riotur.

\begin{abstract}
As primeiras conclusões dos pesquisadores vão de encontro com a hipótese de que se trata realmente de um cemitério de negros. A antropóloga da Prefeitura Eliana Teixeira disse que historicamente a suspeita é mais do que viável. (...) O historiador da Riotur Milton Teixeira também não tem dúvidas de que se trata de um cemitério de negros. (O GLOBO, 1996, p.14).
\end{abstract}

Não há na matéria fala alguma de representantes de movimentos negros que contextualizem a importância do resgate histórico da memória do povo africano no Brasil e, principalmente, no Rio de Janeiro. O negro não recebeu direito a voz. Das cinco fontes consultadas, quatro são ligadas à Prefeitura do Rio de Janeiro. A ausência de pluralidade de vozes na nota e na matéria pode ser interpretada por meio do texto de Foucault (2014), que diz: "ninguém entrará na ordem do discurso se não satisfizer a certas exigências ou se não for, de início, qualificado para fazê-lo. Mais precisamente: nem todas as regiões do discurso são igualmente abertas e penetráveis;”. (FOUCAULT, 2014, p.35)

Não há resgate histórico que relembre ao leitor o significado da descoberta do que é chamado no jornal de "sítio arqueológico". Como explica Alsina (2009), a ênfase é dada ao acontecimento e não às problemáticas que o envolvem, deixando de lado possíveis reflexões que acresceriam ao público uma visão menos rasa sobre os fatos. É deixada de lado, graças ao imediatismo, a principal função do jornalista, a de contextualização do fato. Pode-se identificar na matéria do dia 27 de fevereiro de 1996, de acordo com a Teia das Facilidades elucidada por Nelson Traquina (2005), que elas foram consultadas por estarem momentaneamente em situação de destaque. Traquina (2005) ainda ressalta a importância da distribuição da rede noticiosa, que não deve ser tecida sempre pelos mesmos elementos durante o processo de construção da notícia. O jornalismo restringe, mantendo um número retraído de agentes, os ângulos de visão sobre um mesmo fato que poderiam ser apresentados ao leitor. Ao acontecimento não é dado significado. Não problematiza, ressignifica ou aprofunda, contribuindo para a perpetuação da visão baseada no senso comum do leitor.

Nisto não há nada de espantoso, visto que o discurso (...) não é simplesmente aquilo que manifesta (ou oculta) o desejo; é, também, aquilo que é o objeto; e visto que isso a história não cessa de nos ensinar - o discurso não é simplesmente aquilo que 
traduz as lutas ou os sistemas de dominação, mas aquilo porque, pelo que se luta, o poder do qual nos queremos apoderar. (FOUCAULT, 2014, p.10).

No ano de 1996 foram publicadas, ao todo, duas matérias e duas notas no jornal O Globo que falaram sobre, ou apenas citaram, o Cemitério dos Pretos Novos. A matéria analisada acima, do dia 27 de fevereiro, é a única que traz exclusivamente a necrópole como tema. A segunda matéria, publicada no caderno Rio, é do dia 3 de março, um domingo, e traz como manchete: "Rio sepulta 431 anos de história" (O GLOBO, 1996, p.18). Ela usa a mais recente descoberta para citar vários "tesouros" escondidos no subsolo da cidade.

O primeiro parágrafo refere-se ao Cemitério dos Pretos Novos e conta que "o cemitério de escravos do fim do século XVIII descoberto pela prefeitura nos últimos dias na Gamboa é apenas uma pontinha do iceberg arqueológico"(O GLOBO, 1996, p.18). Passagens subterrâneas, canhões, navios enterrados e ruínas de cidades antigas também são apresentados pelo texto após um breve histórico do Cemitério dos Pretos Novos. Todos são equiparados pela matéria como simples mistérios arqueológicos, exceto três deles, grifados abaixo, que para o jornal $O$ Globo são os mais preciosos:

\begin{abstract}
Mas ainda há muitos outros mistérios escondidos, a poucos metros dos pés dos cariocas. Entre eles, um navio de carga, de 1918, que está enterrado nas areias da Praia de Copacabana, na altura da Rua Belford Roxo. Os tesouros mais preciosos, no entanto, estão indicados num mapa francês anônimo, do século XVI: três baús de ouro estariam enterrados no Rio - um na Praia de Botafogo e os outros dois próximos ao morro Cara de Cão. (O GLOBO, 1996, p.18) ${ }^{6}$
\end{abstract}

A segunda nota a citar o Cemitério dos Pretos Novos foi publicada no caderno Zona Oeste, no último domingo do ano, dia 29 de dezembro de 1996. O título da matéria a qual está anexada é: "Município quer preservar História do Rio". (O GLOBO, 1996, p.3) O primeiro parágrafo explica um projeto da prefeitura que seria implementado. O foco da matéria é esse, a possível implantação de um projeto. "O projeto consiste na implementação, no próximo ano, de centros de referência em arqueologia que permitirão à Prefeitura pesquisar e proteger os locais da cidade onde haja vestígios das antigas civilizações”. (O GLOBO, 1996, p.3)

As três colunas de texto não citam o Cemitério dos Pretos Novos. Porém, uma nota intitulada "Obras do Rio Cidade revelam belos tesouros" (O GLOBO, 1996, p.3) e diagramada dentro de uma caixa de texto, independente ao corpo da matéria, cita ossadas

\footnotetext{
${ }^{6}$ Grifo dos autores.
} 
encontrada em frente à Igreja do Carmo durante obras de drenagem e, nas últimas seis linhas da nota o Cemitério dos Pretos Novos é lembrado. Apenas lembrado.

Todorov (2010), ao falar sobre a Barbárie, aponta que a reafirmação de um senso comum leva a julgamentos absolutos. Durante todo o ano de 1996 falou-se pouco sobre o Cemitério dos Pretos Novos, e quando foi finalmente citado, baús de ouro franceses foram apresentados aos leitores como tesouros mais valiosos. A ideia do capital sobre o cultural é reafirmada. Julgamentos baseados em uma mesma forma de olhar o mundo podem levar a atos bárbaros. O não reconhecimento e valorização de diferentes formas de viver e costumes que integram a cultura aproximam a barbárie da sociedade.

O Instituto de Pesquisa e Memória Pretos Novos (IPN) foi criado no dia 13 de maio de 2005, quase 10 anos após a descoberta do cemitério. O IPN busca propor reflexões, criar projetos educativos e pesquisas para preservar a memória e os acontecimentos do período escravocrata. O Instituto é mantido principalmente por Merced Guimarães, proprietária da casa onde o cemitério foi descoberto, e voluntários de vários segmentos sociais que se identificam com a causa. Realizam um trabalho de resistência, preservação, divulgação e investigação. Merced escreveu em uma de suas redes sociais pessoais, no dia 13 de maio de 2017, aniversário de 12 anos do IPN, que a ideia de criar o Instituto surgiu justamente após a percepção de que nem os governos Federal e Estadual, e muito menos o Municipal, havia se interessado pela descoberta no decorrer de quase uma década. "O descaso na época, foi uma força motriz para criar o IPN, para cuidar da memória de um passado enterrado sob casas para esconder um dos crimes contra a humanidade.” (GUIMARÃES, Merced, 2017)

Em maio de 2005, mês em que o Instituto de Pesquisa e Memória Pretos Novos foi criado, nenhuma matéria que cite-o ou ao Cemitério dos Pretos Novos foi realizada pelo jornal O Globo. Orlandi, em Análise do Discurso (2001), explica que o não-dizer também é carregado de significados. Quando o jornalismo seleciona um fato para que vire notícia ao invés de outro, sua escolha gera significado. Determinado pelo caráter fundador do silêncio, o silêncio constitutivo pertence à própria ordem de produção de sentido e preside qualquer produção de linguagem. Representa a política do silêncio como um efeito de discurso que instala o anti-implícito: se diz "x" para não (deixar) dizer "y", este sendo o sentido a se descartar do dito. É o não-dito necessariamente excluído. Por aí se apagam os sentidos que se quer evitar, sentidos que poderiam instalar o trabalho significativo de uma "outra" formação discursiva, uma "outra" região dos sentidos. O silêncio trabalha assim os limites das 
formações discursivas, determinando consequentemente os limites do dizer. (ORLANDI, 2007, p.73).

O jogo de silenciamento se dá em ambas as matérias na mesma estratégia de valorização que se alia ao discurso político da cidade. A criação do IPN e o descaso do Governo para com o Cemitério dos Pretos Novos foi silenciado pelo jornal $O$ Globo não somente no mês de criação, mas durante todo o ano de 2005. As movimentações que deram início as obras no Porto Maravilha, nome dado a região revitalizada da Zona Portuária da cidade do Rio de Janeiro, começaram no ano de 2010 e se estenderam até 2012, quando efetivamente máquinas começaram a trabalhar no local.

A região compreende uma área de 5 milhões de metros quadrados $\left(\mathrm{m}^{2}\right)$ e engloba os bairros do Santo Cristo, Gamboa, Saúde e trechos do Centro, Caju, Cidade Nova e São Cristóvão. Nela se encontram as partes conhecidas e ainda desconhecidas do Cemitério dos Pretos Novos, assim como outros pontos que reconstituem a história dos escravos africanos na cidade. De acordo com o que a Prefeitura do Rio de Janeiro diz no site oficial do Porto Maravilha, ele "foi concebido para a recuperação da infraestrutura urbana, dos transportes, do meio ambiente e dos patrimônios histórico e cultural da Região Portuária.”. No entanto, com as obras, os bairros da Gamboa e da Saúde passaram por um momento de transformação e grande especulação imobiliária que preocupou historiadores.

A transfiguração do local, para o professor da UFRJ e arqueólogo Reinaldo Tavares (2012), ameaçava principalmente a área apontada nos documentos do século XIX como correspondente ao cemitério. Tentativas de delimitar com exatidão a área revelaram uma gigantesca fertilidade arqueológica em todo o quarteirão onde se encontra o Instituto de Pesquisa e Memória Pretos Novos. Isso motivou um sentimento de proteção patrimonial em historiadores, que criticaram a construção de novas edificações que pudessem afetar a área. Os prédios antigos, com fundações rasas, mantiveram os sítios arqueológicos sem que os fragmentos fossem afetados, o que aconteceria com a construção de estruturas gigantescas. Cientificamente, para eles, ainda há um grande potencial exploratório na área, que compreende o único cemitério exclusivamente destinado a escravos das Américas.

Tavares (2012), após diversas sondagens em obras de reparo da Companhia Estadual de Águas e Esgotos do Rio de Janeiro (CEDAE) na Rua Pedro Ernesto e escavação de poços de estudo dentro do Instituto Pretos novos, concluiu com base na quantidade de lixo urbano encontrado junto aos ossos humanos, cerâmicas e miçangas que: 
O terreno que outrora foi o Cemitério dos Pretos Novos foi utilizado como necrópole e como depósito de lixo urbano. Tal uso foi prolongado até o terreno ser loteado para o mercado imobiliário. Trata-se, no caso, da atividade e da continuidade de um aspecto fortemente simbólico: sendo os negros considerados o lixo da sociedade e descartados como dejetos ao morrerem, mal cobertos por um punhado de terra, utilizou-se, "naturalmente" o uso da área do Cemitério dos Pretos Novos como lixeira, durante a sua atividade como campo santo e nos períodos subsequentes. Somente decorrido um lapso de tempo suficiente para que a memória daquele lugar fosse apagada é que ele foi transformado em área residencial. (TAVARES, 2012, p. 137).

Sobre a discussão envolvendo a construção de empreendimentos imobiliários na região de maior riqueza histórica da cidade e a preservação da Zona Portuária, nenhuma matéria foi encontrada nos registros do jornal $O$ Globo no ano de 2010 e nem nos subsequentes. A única matéria publicada no ano de 2010 sobre o Cemitério dos Pretos Novos foi na editoria História, dia 22 de maio, sábado. O título e subtítulo escolhidos ressaltam as pesquisas que ainda seriam iniciadas pela Universidade Federal do Rio de Janeiro e pela Fundação Oswaldo Cruz a fim de investigar as "ossadas históricas do Rio": "DNA revela origem de escravos: Pesquisadores da UFRJ e da Fiocruz começam investigação em ossadas históricas do Rio”. (O GLOBO, 2010, p. 35) Tanto a UFRJ quanto a Fiocruz são ligadas ao Governo Federal. Governo este que, segundo a presidente do IPN Merced Guimarães, ignorou-os durante uma década. A matéria tem, em grande parte do texto, um teor técnico que busca explicar como as análises de DNA serão feitas, intercalando tais informações com a história da necrópole. São três fontes apresentadas: um professor da UFRJ, uma especialista da Fiocruz e um historiador.

\footnotetext{
As investigações serão feitas pelo exame de trechos curtos na sequência do DNA capazes de apontar ancestralidades. A expectativa é também encontrar vestígios do material genético de parasitas, transmissores de doenças como malária, tuberculose e esquistossomose, responsáveis pela morte de muitos escravos. (O GLOBO, 2010, p. $35)$.
}

Assim como na primeira matéria publicada sobre o Cemitério dos Pretos Novos, ainda em 1996, as fontes consultadas são, em sua maioria, oficiais e ligadas ao governo, seja ele Municipal ou Federal. O foco central da matéria é, justamente, a promessa de um estudo bancado com verbas federais. Ao construir o senso comum e a simbologia dos leitores sobre a necrópole da Gamboa, o jornal $O$ Globo o faz reproduzindo posicionamentos daqueles que ocupam a alta ordem social. O autor Pierre Bordieu (1990) diz que na disputa pelo domínio do 
poder simbólico e produção do senso comum, os títulos de nobreza e os títulos escolares apresentam a propriedade simbólica que dão direito ao reconhecimento da fala.

Se aos negros fosse creditada toda a contribuição cultural e formação histórica da cidade do Rio de Janeiro, o capital simbólico a eles também pertenceria. O reconhecimento de que os negros ajudaram a construir a cidade é negado desde o pós-abolição, quando, segundo Machado (2006), a imprensa começou a estereotipar os recém libertos para que a estrutura social não fosse alterada. A constante contestação da cidadania negra no Brasil desde o século XIX gerou a persistente interdição ao discurso deste grupo, o primeiro e mais evidente mecanismo de exclusão observado por Foucault (2014). A interdição ao discurso se daria quando a relação de poder é exercida sobre ele, o que o autor chama de "terríveis poderes", direitos de privilégio e não de conquista.

O capital simbólico não é outra coisa se não o capital econômico e cultural quando conhecido e reconhecido, quando conhecido segundo as categorias de percepção que ele impõe, as relações de força tendem a reproduzir e reforçar as relações de força que constituem a estrutura do espaço social. (BORDIEU, 1990, p. 163).

Bourdieu (1990) também conclui, com base em autores como Weber e Leniz, que o Estado é o "geometral de todas as perspectivas". Isso significa que todo o poder simbólico, representações sobre os fatos e a violência legitimada, cultual, como dito acima, estão sob o controle do Estado. O Estado julga, determinando as problemáticas que devem ou não ser apresentadas à sociedade, e a imprensa legitima mais uma vez a fala e o poder de violência simbólica. É negada ao negro a possibilidade de disputa pelo poder simbólico, que poderia ser conquistado por meio da visibilidade. O poder de tornar visíveis as divisões e causas sociais implícitas é parte fundamental da luta das classes.

O que pontuamos é como as estratégias de organização da comunicação pelas mídias se articulam a um arcabouço mercadológico de acúmulo e manutenção do capital. Para Sodré (2014), a comunicação é algo que atravessa o social em diversos níveis para além da mídia. Mas é como mídia que ela se materializa; e como tal, é a outra face da acumulação do capital.

(...) "fixar a forma determinada na qual o capital é posto em certo ponto". É esse "certo ponto" que nos parece sobrevir agora ao campo comunicacional, no qual os signos, os discursos, os instrumentos e os dispositivos técnicos são os pressupostos do processo de formação de uma forma nova de socializar, de um novo ecossistema existencial em que a comunicação equivale a um modo geral de organização. Instalada como um mundo de sistemas interligados de produção, circulação e consumo, a nova ordem sociotécnica fixa-se no ponto histórico do aqui e agora, não 
como índice de um novo modo de produção econômico, mas como continuidade, como dominância financeira e tecnológica, da mercantilização iniciada no capitalismo no início da Modernidade ocidental. No necessário rearranjo de pessoas e coisas, a comunicação revela-se como principal forma organizativa. (SODRÉ, 2014, p.14).

É aí que o jornal se torna parceiro das ações da administração pública porque apresenta a questão organizando o dizer, na superficialidade com que pontos complexos são tratados pela lógica da imparcialidade e pelas suas perguntas de objetividade (O quê? Quem? Quando? Como? Onde? Por quê?). E o silêncio não é apenas não dizer, mas dizer uma coisa para não dizer outra, na qual a ardilosidade da prefeitura vai ser negociada discursivamente no jornal. O silêncio, que atravessa as palavras ditas nas matérias do recorte deste trabalho, indica que o sentido sempre pode ser outro daquele que se formula nas palavras textuais das matérias jornalísticas.

Por seu caráter mediador, o jornalismo não se furta do direito de determinar o que é mais importante a ser dito e de articular o caráter deste "mais importante". É na consideração de que todo discurso já é uma fala que conversa com outras falas no processo do interdiscurso, que fica a pergunta: que sentido teria o silêncio das vozes discordantes? O discurso vai justamente ser o efeito de sentido entre os interlocutores. É preciso então compreender que o sentido não está fixado, mas se produz nas relações de força e vai refletir as manifestações e os confrontos ideológicos. Em 2017 o Instituto de Pesquisa e Memória Pretos Novos enfrentou a pior crise financeira desde a sua criação. A CDurp, Companhia de Desenvolvimento Urbano da Região do Porto do Rio de Janeiro, era a gestora da prefeitura na operação Urbana Consorciada Porto Maravilha. Dentre as incumbências da CDurp estaria o repasse e administração de verba do Município destinada ao Instituto de Pesquisa e Memória Pretos Novos desde o início de 2013, quando a contribuição foi acertada. No entanto, o IPN recebeu a última verba municipal em janeiro de 2017. Após a data, a Prefeitura do Rio de Janeiro anunciou a suspensão dos repasses para que uma análise no orçamento para os anos de 2017 e 2018 fosse realizada.

Sem ter como custear as atividades oferecidas, o Instituto cancelou palestras e oficinas. Apenas para o custeio de contas básicas são gatos 8 mil reais mensais. Desde janeiro de 2017 o valor tem sido levantado por meio de doações de voluntários e, principalmente, pela vontade da Merced de manter ao menos o museu com as portas abertas. 
A única matéria sobre a crise financeira que atinge o IPN foi publicada no jornal $O$ Globo até o fechamento do presente trabalho foi no dia 28 de março de 2017, no final da página 10 do caderno Rio. A primeira parte do texto conta um pouco sobre como foi a compra da casa por Merced Guimarães e a descoberta do Cemitério dos Pretos Novos, seguindo-se de um breve histórico e de apenas um curto parágrafo, apresentado abaixo, que informa sobre a falta de repasses da CDurp.

\footnotetext{
Apesar da riqueza histórica, o instituto corre o risco de fechar as portas. Merced Guimarães contou que, no início do mês, foi comunicada pela direção da Companhia de Desenvolvimento Urbano da Região do Porto do Rio (CDurp), órgão da prefeitura, que o convênio que previa o repasse de $\mathrm{R} \$ 6$ mil mensais para o custeio da casa não será renovado. A companhia informou que "vai reposicionar seus contratos" após análise dos orçamentos de 2017 e 2018. (O GLOBO, 2017, p. 10)
}

As fontes consultadas incluem o professor da UFRJ e arqueólogo Reinaldo Tavares, também citado neste trabalho. Porém, as duras críticas feitas por Reinaldo à forma como o Cemitério dos Pretos Novos foi tratado desde o encerramento oficial de suas atividades em 1830 até a reforma da Zona Portuária em 2010 não foram ouvidas, muito menos a declarada opinião contrária ao incentivo do governo à especulação imobiliária.

Segundo o arqueólogo Reinaldo Tavares, que desde 2008 faz pesquisas no Pretos Novos, é difícil estimar quantas pessoas foram enterradas naquele terreno que tinha o tamanho de um campo de futebol. O que restou de um livro de anotações da época mostra que, somente entre 1824 e 1830, aconteceram 6.122 sepultamentos de escravos, de acordo com registros do Arquivo Geral da Cidade do Rio de Janeiro. Não havia lápides, e os corpos eram colocados em covas coletivas. (O GLOBO, 2017, p. 10)

O subtítulo "Relíquias Históricas" divide a segunda parte da matéria, que enumera outros endereços que devem ser visitados na região portuária do Rio. São citados, dentre outros, o Cais do Valongo, o Jardim Suspenso do Valongo, a Pedra do Sal e a Praça dos Estivadores. Os pontos turísticos são todos ligados à memória negra, mas a apresentação deles ocupa metade do corpo do texto e desvia o foco do problema apresentado no título: "No porto, instituto que preserva memória da escravidão pode fechar”. (O GLOBO, 2017, p.10) No fim das contas, a matéria de seis colunas resumiu todo o problema financeiro do IPN em um parágrafo, já citado acima. Abaixo destaca-se a abertura da segunda parte do texto: "para a historiadora Martha Abreu, além do cemitério, que ajudou a desenterrar a história da Pequena 
África na década de 1990, a região do porto tem pelo menos outros 17 endereços que merecem ser visitados." (O GLOBO, 2017, p. 10).

Como esclareceu Pena (2005), por meio da teoria do agendamento, ou agenda-setting, a imprensa é responsável não só pelos assuntos que entram na pauta das discussões em sociedade, mas também pelo posicionamento que o público terá em relação a eles. Diante da matéria, o público estará informado sobre o possível fechamento de um instituto de grande importância, mas não compreenderá exatamente quais são as questões financeiras que estão se desenrolando e o que o IPN tem feito para tentar resistir à crise. Saberá também que, mesmo que o Cemitério feche as portas, outros 17 endereços continuarão disponíveis para a visitação. A importância do instituto é minimizada. A crise financeira disputa espaço com um guia turístico.

\section{"Tristeza mais triste é aquela que não se ouve",}

Em “É isto um homem?”, Primo Levi (1988) vai descrever os sonhos constantes dos presos nos campos de concentração durante a Segunda Guerra Mundial. Nestes sonhos algo em comum: o desespero por não encontrarem quem quisesse ouvir os relatos dos horrores vividos. Ouvir as palavras ditas, escutar as narrativas deveria ser a função dos ouvintes, que, em vez disso vão embora, não querem saber e nem permitir que essa história difícil e ameaçada por sua própria impossibilidade, os alcance e ameace também a tranquilidade de sua vida cotidiana. Jeanne Marie Gagnebin (2006) vai justamente se preocupar em ampliar o conceito de testemunha.

Para ela, a testemunha não seria somente aquele que viu com seus próprios olhos, mas seria também aquele que não vai embora, que consegue ouvir a narração insuportável do outro e que aceita que suas palavras levem adiante a história: não por culpa ou por compaixão, "mas porque somente a transmissão simbólica, assumida apesar e por causa do sofrimento indizível, somente essa retomada reflexiva do passado pode nos ajudar a não repeti-lo infinitamente, mas a ousar esboçar uma outra história, a inventar o presente.” (Gagnebin, 2001, p. 57).

É então da incapacidade de ouvir relatos, de fazer valer a condição de pluralidade em que os pontos, divergentes ou não, são postos no tabuleiro de um texto, que o jornalismo burla sua condição de testemunha ao se estruturar em práticas que retiram o potencial transformador

\footnotetext{
${ }^{7}$ Grifo dos autores.

${ }^{8}$ COUTO, Mia. Vozes Anoitecidas, Cia das Letras, 2013, p.62.
} 
do jornalismo deixando-o apoteoticamente como palco de recursos políticos hegemônicos. A prerrogativa de não dar conta do real em sua transposição ao texto é essência do jornalismo, no entanto não pode ser usada como justificativa para a apatia desconcertante e ardilosa com que as vozes, a história, as narrativas "enterradas" dos pretos novos são apagadas pelo uso de recursos legítimos da rotina jornalística.

\begin{abstract}
O silêncio é o resultado do silenciamento: a cultura ocidental e a modernidade têm uma ampla experiência histórica de contato com outras culturas, mas foi um contato colonial, um contato de desprezo, e por isso silenciaram muitas dessas culturas, algumas das quais destruíram. Por isso, quando queremos tentar um novo discurso ou teoria intercultural, enfrentamos um problema: há nos oprimidos aspirações que não são proferíveis, porque foram consideradas improferíveis depois de séculos de opressão. (SANTOS, 2007, p.55).
\end{abstract}

Esse fingir ouvir da pseudo-condição de testemunha do jornalismo traz um questionamento fundamental ao papel não só do jornalismo, mas especificamente ao papel dos silenciados - como questiona Boaventura de Sousa Santos (2007): "como fazer o silêncio falar de uma maneira que produza autonomia e não a reprodução do silêncio?"

Rastros, então, como a ligação, a experiência de mundo de marcação da presença registro na memória do mundo da existência. É nesse ponto que o jornalismo transforma em vestígios a presença (que é concreta) dos negros escravizados, seja na proposta de especulação imobiliária para a região, seja no apagamento do museu (o único na América Latina) e da própria história. Podemos compreender a partir do conceito de dislexia discursiva (Sousa, 2017) que assegura ao jornalismo a potência das estratégias de manutenção e legitimação de consensos como uma forma de imobilizar resistências.

\footnotetext{
Não se trata de pensar o jornalismo dislexo como essência. Ou em outras palavras, um jornalismo dislexo por não ser capaz de dar conta do mundo à volta como se fosse apenas incapacidade pela tentativa. Ou de propor uma concepção da imprensa cuja impossibilidade de dar conta da verdade seja compreendida como condição possível - já que se encontraria inevitavelmente na busca por tatear o real. Não negamos tais impossibilidades do jornalismo, o que queremos defender aqui é como tais considerações mascaram o uso das limitações com ardilosas ferramentas de orquestração acintosa dos direcionamentos do sentido. Ou seja, o jornalismo promove como estratégia discursiva a dislexia da fala do outro. (SOUSA, 2017, p. 110).
}

Em Experiência e Pobreza, Benjamin (2012) alerta justamente para como os homens aspiram por libertar-se de toda experiência e encontram refúgio às suas mazelas na exaustão e saciedade do cotidiano. É o que trazemos para pensar o jornalismo, aquele que não se atém a 
complexificar os processos alinhavados ao que se entende por integração - e reduz a experiência do outro a uma fala sem historicidade, sem antagonismos, sem percalços - deixa apenas o rastro de sua existência.

É interessante então percebermos que nosso trabalho de pesquisa aqui se assemelha ao do arqueólogo pela busca da descoberta e compreensão daquilo que está distante no tempo. Assim, é pelo rastro que podemos nos apoderar do conhecimento longínquo que está do outro lado dele. Permitir-nos, como afirmou Gagnebin (2001), escavar, retirar a terra para encontrar a cova. Fica claro então que é pela escavação das matérias que podemos propor uma compreensão de como se processam os dizeres outros - senão como ditos, mas apresentados pela imprensa. É como rastro que se reitera a posição de túmulo no presente, o que faz do processo de rememorar tão valioso quanto o objeto que se encontra na memória, porque a trajetória ao encontro do passado modifica também o presente.

O rastro, na tradição filosófica e psicológica, sempre foi uma dessas noções preciosas e complexas que procuram manter juntas a presença do ausente e a ausência da presença da qual nos diz Benjamin. O rastro faz-nos lembrar de algo que não existe mais e que sempre corre o risco e se perder definitivamente no tempo.

\footnotetext{
Por que a reflexão sobre a memória utiliza tão frequentemente a imagem $-\mathrm{o}$ conceito - de rastro? Porque a memória vive essa tensão entre a presença e a ausência, presença do presente que se lembra do passado desaparecido, mas também presença do passado desaparecido que faz sua irrupção em um presente evanescente. Riqueza da memória, certamente, mas também fragilidade da memória e do rastro. Podemos também observar que o conceito de rastro rege igualmente todo o campo metafórico e semântico da escrita, de Platão a Derrida. Se as "Palavras" só remetem às "coisas" na medida em que assinalam igualmente sua ausência, tanto mais os signos escritos, essas cópias de cópias como diz Platão, são, poderíamos dizer deste modo, o rastro de uma ausência dupla: da palavra pronunciada (do fonema) e da presença do "objeto real" que ele significa. (GAGNEBIN, 2006, p. 44).
}

O Cemitério dos Pretos Novos corre o risco de fechar as portas e deixar de ser um local de memória e de resistência de um país cuja história tenta se despregar das barbáries cometidas em nome de um projeto de país. Os escravos sepultados nas valas rasas não têm nome completo, não tem família, não tem história, não são heróis brasileiros e não se fazem presentes nem na memória coletiva da população e nem na da mídia.

Todas as matérias publicadas nos anos escolhidos para análise ignoraram a existência de movimentos negros que pudessem falar sobre o resgate histórico dos milhares de negros depositados na Gamboa. Ou então, que criticassem o abandono do cemitério por parte do 
governo. Aprofundamento histórico também não houve. Alguns fatos nem nota mereceram. Todas as publicações, nos anos analisados entre 1996 e 2017, ouviram fontes ligadas aos governos municipal, estadual ou federal. Mesmo quando a história do holocausto negro insiste em ressurgir, como aconteceu no Rio de Janeiro, ela não é vista. Quando a memória dos negros cativos pede socorro, como em 2010 e em 2017, o grito se transforma em poucas linhas no jornal ou em nenhuma. Não é difícil compreender os motivos que fizeram com que os estereótipos dedicados ao negro ainda no século XIX se perpetuassem. A cidadania, a cultura e a contribuição negra para a história do país continuam sendo negadas. Como o jornalismo pode então ser redentor e articulador do social e do político se promove a dislexia da voz dos sujeitos do "outro lado da balança"?

\section{Referências}

ALSINA, Miquel Rodrigo. A construção da notícia. Rio de Janeiro: Editora Vozes, 2009. BENJAMIN, Walter. Mágia e técnica, arte e política: ensaios sobre literatura e história da cultura. São Paulo: Brasiliense, 2012.

BORDIEU, Pierre. Coisas ditas. São Paulo: Brasiliense, 1990.

COUTO, Mia. Terra Sonâmbula. São Paulo: Cia das Letras, 1992.

COUTO, Mia. Vozes Anoitecidas. São Paulo: Cia das Letras, 2013.

FOUCAULT, Michael. A ordem do discurso: aula inaugural no Collège de France, pronunciada em 2 de dezembro de 1970, 24º ed. São Paulo: Editora Loyola, 2014.

GAGNEBIN, Jeanne Marie. Lembrar Escrever Esquecer. São Paulo: Editora 34, 2006.

Memória e (res)sentimento: indagações sobre uma questão sensível.

Orgs. Stella Bresciani e Márcia Naxara. São Paulo: Ed. Unicamp, 2001. 552 p.

LEVI, Primo. É isto um homem? Rio de Janeiro: Rocco, 1988.

MACHADO, Humberto Fernandes. Imprensa e Identidade do ex-escravo no contexto do pósabolição. In: Neves, Lúcia M,B,P; Morel, M.; Bessone, Tânia. (Org.). História e Imprensa: representações culturais e práticas de poder. Rio de Janeiro: DP\&A: FAPERJ, 2006, v. 1, p. 142-152;

ORLANDI, P. Eni. Análise de Discurso: princípios e procedimentos. Campinas, SP: Editora Pontes, 2001. 
PEREIRA, Júlio César Medeiros da Silva. À flor da terra: o cemitério dos pretos novos no Rio de Janeiro. Rio de Janeiro: Garamond: IPHAN, 2007.

SANTOS, Boaventura de Sousa. Renovar a teoria crítica e reinventar a emancipação social. São Paulo: Boitempo, 2007.

SODRE, Muniz. A Ciência do Comum. Petrópolis: Vozes, 2001.

Claros e Escuros: Identidade, povo e mídia no Brasil. $3^{\text {a }}$ ed. Rio de Janeiro:

Editora Vozes, 2015.

SOUSA, Mônica. O jornalismo que cala a periferia. A dislexia discursiva e o silenciamento da pobreza. Sur le journalisme, About journalism, Sobre jornalismo, [S.1.], v. 6, n. 1, p. $102-$ 115, juin 2017.Disponible à l'adresse : $\langle$ http://surlejournalisme.com/rev/index.php/slj/article/view/293 $>$.

TAVARES, Reinaldo Bernardes. Cemitério Dos Pretos Novos, Rio De Janeiro, Século XIX: Uma Tentativa De Delimitação Espacial. In: Representação Regional da Fundação Cultural Palmares/MINc, 2010. Disponível em: <portomaravilha.com.br/conteudo/estudos/ea2.pdf> Acessado em 02 de maio de 2017.

TODOROV, Tzvetan. O Medo dos Bárbaros: para Além do Choque das Civilizações. Rio de Janeiro: Editora Vozes, 2010.

TRAQUINA, Nelson. Teorias do Jornalismo: Porque as notícias são como são. $2^{\mathrm{a}}$ ed. Santa Catarina: Editora Insular, 2005. 